\section{Continued from page 11}

they have been subject to some form of penal control for political expression, and are able to become successfully established in Canada. Four Latin American countries and Poland are in this class.

In addition to the designated classes, there are special procedures for persons from countries experiencing adverse domestic events. There are currently nine countries for which special procedures are in effect. The procedures vary from country to country, but typically they do not permit deportation back to the country of origin. Relatives not in the family class may sponsor persons from these countries.

I do not suggest that these procedures cease. On the contrary, when the government tried to impose more stringent regulations on the self-exiled class, to make it more difficult to defect from Eastern Europe, I objected. What I do say is that these special procedures point out the importance of making our refugee determination procedure work fairly. With a fair refugee determination procedure, some of these special rules would not be necessary. The people who are taking advantage of them could simply claim refugee status.

\section{Conclusion}

Canada has come from being a country, in the space of a few decades, where racism was prevalent to a country where respect for human rights is universally accepted, at least in principle. However, there is a big step from principle to practice. The goal of racial equality is stated in our Immigration Act and in our Charter. To reach that goal, there is still work to do.

David Matas, a Winnipeg lawyer, is Legal Counsel to the League for Human Rights of B'nai Brith Canada. The first part of this paper was published in our last issue of Refuge (December 1985).

\title{
Refugee or Asylum: A Choice for Canada?
}

\section{An International Symposium, May 27-30, 1986}

The Refugee Documentation Project of York University will host an international symposium, Refuge or Asylum: A Choice for Canada? at Glendon College, York University, Tuesday through Friday, May 27-30, 1986.

The Organizing Committee, Professors Michael Lanphier (Sociology, York University) and Howard Adelman (Philosophy, York University) and Dr. Lubomyr Luciuk (Geography, University of Toronto), have invited scholars, representatives of governments and non-governmental organizations from Europe and North America to present research papers and to guide seminar sessions on an integrated set of topics relating asylum and refuge as two types of resolutions for involuntary migrants.

This symposium highlights a number of issues arising in policy formulation by governments, especially the Canadian government, and non-governmental organizations with respect to contemporary refugee movements, pertinent ethnocultural history, policy of multi-culturalism and resettlement activities.

In that context, however, it brings forward the status of political asylum, which has to date not received appropriate systematic attention in conceptualization about the refugee experience. Although considered by policy makers in the Canadian government, asylum has not been acknowledged as a viable alternative to refugee status for involuntary migrants arriving in Canada.

This symposium draws attention to the policies and practices of refugee recognition, eligibility determination, and selec- tion. This focus is highlighted by comparison of the Canadian experience with those in the United States and European receiving countries.

Specific case materials will be presented by specialists in the respective fields. The experience of resettlement and return of refugees from Latin America will receive special attention in light of Canada's important involvement with that area.

The symposium attempts to bring a more common level of discourse and exchange between government and NGOs. The complementary nature of their contributions will be further mediated by the role of academic intervention, which attempts order and focuses upon the process of creating this order, as prerequisite to the realization of operational goals.

The organizing committee notes that while a symposium may be a short-lived event, the products of it are otherwise. Personal acquaintances among members of varied professional backgrounds and interests can be made and renewed. A symposium is an excellent and productive occasion for exchange to proceed from its commencement there. The proceedings will be edited by the three collaborators (Lanphier, Adelman, Luciuk) and Alex Zisman, Conference Co-ordinator, for publication as a scholarly book, tentatively to be given the same title as the symposium.

For further information and registration, contact the Refugee Documentation Project, 241 H Administrative Studies Building, York University, 4700 Keele Street, North York, Ontario M3J 1P3. 